UDC 663.551.1:634.8

COBISS.SR-ID: 220301836

Original research paper

Acta Agriculturae Serbica, Vol. XX, 40 (2015); 117-125

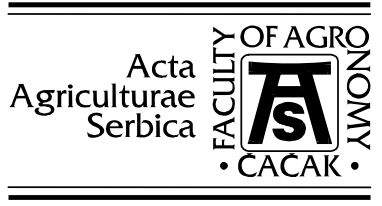

\title{
Effect of alcoholic fermentation on the quality of grape brandies
}

\author{
Vera Vukosavljević ${ }^{1}$, Ranković Vesna ${ }^{2}$, \\ Dragoljub Žunić ${ }^{3}$, Saša Matijašević ${ }^{3}$ \\ ${ }^{1}$ Faculty of Agronomy, Cara Dušana 34 Čačak, Serbia (verav@kg.ac.rs) \\ ${ }^{2}$ Centre of Viticulture and Viniculture, Kolonija EL 6, Niš, Serbia \\ ${ }^{3}$ Faculty of Agriculture, Zemun, Nemanjina 6, Belgrade, Serbia
}

\begin{abstract}
Grape brandy is a product obtained by fermentation and distillation of crushed grapes of cultivated grapevine Vitis vinifera. Grape brandy quality depends on many factors such as: grapevine varieties, climate, soil, time and method of distillation, storage methods and other distillates. The grapevine variety 'Neoplanta' grown in the experimental field of the PD "Center for Viticulture and Enology" in Niš was used in the experiment. Tests were performed in the laboratory of the Centre. Healthy grapes of harvest maturity were squashed by a stalk-removing electric crusher. Fermentation was performed in plastic containers in the presence of the indigenous microflora of wine yeasts. This paper presents the influence of $\mathrm{pH}$ and inorganic nitrogen added to the fermentation medium on the content of volatile components and concentrations of higher alcohols.
\end{abstract}

Key words: grape brandy, grape, higher alcohols, variety, Neoplanta

\section{Introduction}

Grape brandy is a product made by fermentation and distillation of grape pomace of cultivated grapevine Vittis vinifera (Lučić 1986; Paunović and Đurišić

Received: 5 August 2015 / Accepted: 19 November 2015 
1981). Grape brandy quality depends on many factors: grapevine variety, climate, land, agricultural practices, yield, fermentation characteristics, timing and methods of distillation, storage methods and other distillates (Nikićević et al. 2000; Paunović and Nikičević 1986; Petkov et al. 1998; Stanković et al 1998).

Water and ethanol are the main volatile ingredients of alcoholic beverages, followed by methanol and higher alcohols (Paunović 2000). Higher alcohols are formed during fermentation, and they affect the quality of a beverage and its sensory properties. In addition, higher alcohols contribute to the formation of

flavor. Unfortunately, problems arising due to excessive consumption of beverages are partially attributed to higher alcohols which, considering their action, belong to drugs.

This research was conducted to study the impact of alcoholic fermentation on the concentration of higher alcohols in 'Neoplanta' grapevine brandy. Quality parameters of the grape brandies produced were determined by standard methods in accordance with the Rules on the Methods of Sampling and Performance of Chemical and Physical Analyses of Alcoholic Beverages (Regulations on Sampling Methods and Physical and Chemical Analyses of Spirits (1987). Higher alcohols were assessed by the gas-chromatographic method.

The GC method for the quantitative determination of volatile components in alcoholic beverages prescribed by the Office International de la vigne et du vin, Recueil des methodes internationales d'analyse des boissons spiritueses, des alcools et de la fracton aromatique boissons (OIV 1994) is an internal standard method, with 4-methyl-2-pentanol as the internal standard, column Carbowax 1540 isothermal temperature regime of $40^{\circ} \mathrm{C}$, linear increase of $4{ }^{\circ} \mathrm{C} / \mathrm{min}$ to $200^{\circ}$ C. Some analysts determine higher alcohols in wine using column Carbowax 1500, with n-butanol as the internal standard, and temperature is controlled by increasing injector temperature to $8^{\circ} \mathrm{C}$ after leaving the peak (Lee and Cooly 1981). Retention times of methanol 0.77 , ethanol 1.49 , n-propanol 3.23, isobutanol 6.53, n-butanol - 8.16 internal standard, isoamylalcohol 14, 19. In some studies, the $\mathrm{GC}$ method with flame ionization detector was used to determine the parameters (ethyl acetate, 2-butanol, 1-propanol, 2-methyl-1propanol, 21-ol, 1-butanol, 2- methyl-1-butanol, 3-methyl-1-butanol) under similar conditions (Boscolo et al. 2000; Miranda et al. 1985).

\section{Materials and methods}

Grapes of grapevine cultivar 'Neoplanta' grown in the experimental field of the PD "Center for Viticulture and Enology" in Niš were used in the experiment. Tests were performed under laboratory conditions at the Centre. Healthy grapes of harvest maturity were mashed by a stem-removing electric crusher. The fermentation of the whole grape pomace was performed in plastic containers in the presence of the indigenous microflora of wine yeasts. Distillation and 
redistillation of fermented pomace were performed using discontinuous-type distillation apparatus of $10 \mathrm{~L}$ volume. The first distillation was designed to maximize the exploitation of alcohol without separation into fractions. Redistillation involved separation into fractions, as follows:

- $\quad$ The first faction - $1 \%$ of the still,

- Heart binding constraint - central stream which has an average of $55 \mathrm{vol} \%$ alcohol

- Weak brandy - last distillate stream to the maximum alcohol exploited.

The obtained distillates were stored in glass balloons, and after 6 months physically and chemically partially stabilized brandies were analyzed.

The experiment was set up in six variants according to the design given in Table 1.

Table 1. Experimental variations

\begin{tabular}{|c|c|}
\hline $\begin{array}{l}\text { Experimental } \\
\text { variant }\end{array}$ & Experimental conditions \\
\hline Variant 1 & fermentation at $20^{\circ} \mathrm{C}$ \\
\hline Variant 2 & fermentation at $30^{\circ} \mathrm{C}$ \\
\hline Variant 3 & $\begin{array}{l}\mathrm{pH} \text { adjustment to } \mathrm{pH} 3 \text { by addition of } \mathrm{H} 2 \mathrm{SO} 4 \text { to the medium, } \\
\text { fermentation at } 20^{\circ} \mathrm{C}\end{array}$ \\
\hline Variant 4 & $\begin{array}{l}\mathrm{pH} \text { adjustment to } \mathrm{pH} 3 \text { by addition of } \mathrm{H} 2 \mathrm{SO} 4 \text { to the medium, } \\
\text { fermentation at } 30^{\circ} \mathrm{C}\end{array}$ \\
\hline Variant 5 & $\begin{array}{l}\text { addition of } 0.6 \mathrm{~g}(\mathrm{NH} 4)_{2} \mathrm{HSO} 4 \text { per kg of pomace, fermentation at } 20 \\
{ }^{\circ} \mathrm{C}\end{array}$ \\
\hline Variant 6 & $\begin{array}{c}\text { addition of } 0.6 \mathrm{~g}(\mathrm{NH} 4)_{2} \mathrm{HSO} 4 \text { per kg of pomace, fermentation at } 30 \\
{ }^{\circ} \mathrm{C}\end{array}$ \\
\hline
\end{tabular}

The quality parameters of grape brandies produced were determined by standard methods laid down in the Rules on the Methods of Sampling and Performance of Chemical and Physical Analyses of Alcoholic Beverages. Higher alcohols were analyzed by gas-chromatography.

The applied method is a GC internal standard, with 1-butanol as the internal standard. Analysis was performed on a Varian 3400 with flame ionization detector (FID). Operating conditions were as follows: nitrogen flow rate $20 \mathrm{ml} /$ min, the flow rate of hydrogen $20 \mathrm{ml} / \mathrm{min}$, air flow rate $200 \mathrm{ml} / \mathrm{min}$, column Carbowax 20M, injector temperature $120{ }^{\circ} \mathrm{C}, 160^{\circ} \mathrm{C}$ temperature detectors, temperature conditions: starting temperature of $40{ }^{\circ} \mathrm{C}$, linear increase of temperature $40^{\circ} \mathrm{C}$ to $160^{\circ} \mathrm{C}, 8^{\circ} \mathrm{C} /$ minute to $160^{\circ} \mathrm{C}$ without holding the final temperature, the amount of injected sample $1 \mu$ l. The qualitative and quantitative 
determination of 1-propanol, isobutanol, isoamyl alcohol and amyl alcohol was performed.

\section{Results and Discussion}

The chemical composition of grape brandies is shown in Table 2.

The chemical quality parameters of the experimental grape brandies are in accordance with legal regulations, the Ordinance on the Quality of Alcoholic Beverages, Official Gazette 4/2003.

Experimental results showed that the total acid content and esters of methanol were lower in the variant involving fermentation at $20^{\circ} \mathrm{C}$ (variants 1,3 and 5), compared to variants in which fermentation took place at $30^{\circ} \mathrm{C}$ (variants 2, 4 and 6) (Flanzy et al. 1968; Jović 1992; Lee and Cooly 1981). The concentration of total aldehyde and furfural was higher in grape samples undergoing fermentation at a higher temperature, $30{ }^{\circ} \mathrm{C}$ (Variant 2) (Flanzy et al.1968; Lee and Cooly 1981 and Miranda et al.1985).

The concentration of higher alcohols generated during fermentation depends on a number of factors, such as amino acid composition, the concentration of ammonium salt in the fermented mixture, fermentation temperature, yeast, etc.

At lower nitrogen content up to $300 \mathrm{mg} / 1$, the amount of higher alcohol rises to the maximum, when it starts to decrease until the end of fermentation, despite the further increase in nitrogen. This rule applies to higher alcohols having corresponding amino acid precursors. In the case of 1-propanol, which has no corresponding amino acid precursor, the formation continues with increasing nitrogen up to $500 \mathrm{mg} / \mathrm{l}$. This is interpreted as the predominant formation of sugar.

It is believed that the relationship between the amount of amino acids (more than twenty were identified in the grapes) and higher alcohols in wine is strongly determined by varietal specificity. The amino acid composition indicates the metabolic processes occurring during the growing season and grape maturation. The amino acid composition provides information about the time of separation of wine from the litter (Pekka 1996). Paunovic R. quoting Rodopula (Paunović 2000) states that the increase of the concentration of amino acids is related to generated higher alcohols; 1-propanol and isobutanol increase, and the amount of pentanol declines. The experimental results confirm that the addition of inorganic nitrogen led to a reduction in the concentration of higher alcohols compared to the control (Puškaš 2002). 
Table 2. Chemical composition of experimental 'Neoplanta' grape brandies

\begin{tabular}{|c|c|c|c|c|c|c|}
\hline $\begin{array}{l}\text { Investigation } \\
\text { Parameter }\end{array}$ & $\begin{array}{c}\text { Variant } \\
1\end{array}$ & $\begin{array}{c}\text { Variant } \\
2\end{array}$ & $\begin{array}{c}\text { Variant } \\
3\end{array}$ & $\begin{array}{c}\text { Variant } \\
4\end{array}$ & Variant 5 & Variant 6 \\
\hline $\begin{array}{l}\text { Relative density } \\
\text { at } 20^{\circ} / 20^{\circ} \mathrm{C}\end{array}$ & 0.9205 & 0.9191 & 0.9122 & 0.9196 & 0.9192 & 0.9228 \\
\hline Alcohol, vol $\%$ & 55.59 & 56.25 & 59.42 & 56.02 & 56.21 & 54.50 \\
\hline Total acids, mg/L & 442.3 & 69.8 & 221.2 & 128.0 & 279.4 & 46.6 \\
\hline Esters, $\mathrm{mg} / \mathrm{Laa}$ & 3466.0 & 1120.0 & 4839.0 & 1193.0 & 2119.0 & 694.0 \\
\hline Methanol, g/Laa & 1.65 & 1.40 & 2.44 & 1.36 & 2.03 & 1.71 \\
\hline $\begin{array}{c}\text { Total aldehydes, } \\
\text { mg/Laa }\end{array}$ & 107.5 & 258.0 & 129.3 & 259.0 & 91.1 & 125.3 \\
\hline Furfural, mg/Laa & 1.3 & 3.2 & 0.9 & 2.9 & 1.0 & 1.1 \\
\hline $\begin{array}{l}\text { Total higher alcohols, } \\
\text { mg/Laa, GC-method }\end{array}$ & 2870.40 & 3545.41 & 2688.21 & 3372.92 & 2669.64 & 3170.85 \\
\hline Propanol mg/Laa & 208.68 & 137.92 & 127.46 & 107.97 & 200.88 & 181.97 \\
\hline Isobutanol mg/Laa & 453.31 & 628.89 & 492.13 & 596.14 & 445.88 & 547.26 \\
\hline Isopentanol $\mathrm{mg} / \mathrm{Laa}$ & 2004.74 & 2717.25 & 2023.47 & 2564.97 & 1988.29 & 2321.41 \\
\hline Pentanol mg/Laa & 203.67 & 64.35 & 45.15 & 103.84 & 34.59 & 120.21 \\
\hline Isopentanol/isobutanol & 4.4 & 4.3 & 4.1 & 4.3 & 4.4 & 4.2 \\
\hline Isobutanol/propanol & 2.2 & 4.5 & 3.8 & 5.5 & 2.2 & 3.0 \\
\hline Isopentanol/propanol & 9.6 & 19.70 & 15.9 & 23.7 & 9.9 & 12.8 \\
\hline
\end{tabular}

The minimum concentration of higher alcohols was determined in Variant 5 which involved the addition of inorganic nitrogen and fermentation at $20^{\circ} \mathrm{C}$, followed by Variant 3 for which $\mathrm{pH}$ of the fermentation medium was adjusted.

If we consider the temperature factor, the content of higher alcohols was lower in variants subjected to fermentation at $20^{\circ} \mathrm{C}$ (Variants 1,3 and 5). The highest concentration of propanol increases at the fermentation temperature of $18^{\circ} \mathrm{C}$ (Paunović 2000). The concentration of propanol in the experimental grape 
brandy for variants in which fermentation took place at $20^{\circ} \mathrm{C}$ (Variants 1,3 and 5) was expectedly higher than in variants subjected to fermentation at $30^{\circ} \mathrm{C}$.

Propanol content was higher in the variant with inorganic nitrogen added (Variants 5 and 6) and fermentation of pentanol until the concentration was higher in the variant where fermentation took place at $30^{\circ} \mathrm{C}$ (Paunović, (2000).

Variants involving $\mathrm{pH}$ adjustment of the fermentation medium (Variants 3 and 4) resulted in reduced content of higher alcohols compared to the control.

The highest content of isobutane and isopentanol was determined in Variant 2 during fermentation at $30{ }^{\circ} \mathrm{C}$, without correction of the fermented medium, and lowest in Variant 5 which involved fermentation at $20{ }^{\circ} \mathrm{C}$ with the addition of inorganic nitrogen.

The minimum content of pentanol was determined in Variants 5 and 3 $34.59 \mathrm{mg} /$ La.aa and $45.15 \mathrm{mg}$ / La.aa, respectively.

The ratio of isopentanol / isobutanol in experimental grape brandies ranged from 4.1 (Variant 3) to 4.4 (Variants 1 and 5). The ratio of isobutanol / propanol ranged from 2.2 (Variants 1 and 5) to 5.5 (Variant 4), isopentanol / propanol 9.6 (Variant 1) to 23.7 (Variant 4). The ratios of tested higher alcohols are consistent with research in this field. The ratio of isobutanol / propanol in Variant 4 was 5.5, maximum ratio 4, isopentanol / ropanol 23.7, previous maximum determinations 20 (Petkov et al.; Stanković et al. 1998). The resulting deviations in Variant 4 were expected because this grape fermentation occurred at $20^{\circ} \mathrm{C}$ with the addition of inorganic nitrogen.

\section{Conclusion}

These results suggest the following:

Chemical quality parameters of experimental grapes are in accordance with legal regulations, the Ordinance on the Quality of Alcoholic Beverages, Official Gazette 4/2003.

The experimental samples of grape brandies obtained by fermentation at $20^{\circ}$ $\mathrm{C}$ have a lower content of acids, esters and methanol compared to corresponding solutions at $30^{\circ} \mathrm{C}$.

The concentration of total aldehyde and furfural were higher in variants in which fermentation occurred at $30^{\circ} \mathrm{C}$.

The lowest concentration of higher alcohols was determined in the experimental variant involving the addition of inorganic nitrogen and fermentation at $20^{\circ} \mathrm{C}$, followed by Variant 3 involving $\mathrm{pH}$ adjustment.

The content of higher alcohols was lower in variants with fermentation occurring at $20^{\circ} \mathrm{C}$.

Variants involving $\mathrm{pH}$ adjustment of the fermentation medium led to a reduced content of higher alcohols compared to the control. 
The highest contents of isobutanol and isopentanol were determined in Variant 2, fermentation at $30^{\circ} \mathrm{C}$, without correction, and lowest in Variant 5, fermentation at $20^{\circ} \mathrm{C}$, addition of inorganic nitrogen.

The minimum content of pentanol was determined in variants involving fermentation at $20^{\circ} \mathrm{C}$, $\mathrm{pH}$ adjustment and inorganic ammonia addition.

The ratio of isobutanol / propanol ranged from 2.2 to 5.5, isopentanol / propanol 9.6 to 23.7 .

\section{References}

Boscolo, M., Bezerra, W.B.C., Cardoso, R.D., Lima Neto S.B., Franco, W.D. (2000): Identification and dosage by HRGC of minor alcohols and esters in Brazilian sugar-cane spirit. Journal of Brazilian Chemical Society 11/1, 1-8.

Flanzy, M., Poux, C., Dupuly, P. (1968): Fementation du mout de raisin en continu, Formation des alcools superieurs. VITIS, Viticulture and Enology, 17, 207215.

Jović, S. (1992): Uticaj načina prerade grožđa i načina vinifikacije na sadržaj metanola i važnijih viših alkohola u vinu. Doktorska disertacija, Novi Sad

Lee, C.Y., Cooly, H.J. (1981): Research note Higher Alcohol Contents in New York Wines. American Journal of Enology and Viticulture, 32/3, 244-247.

L u č ić, R.(1986): Proizvodnja jakih alkoholnih pića. Nolit, Beograd.

Miranda, L., Campos, A., Cerdeira, A. (1985): Validation of the method for the determination of ethanol, ethyl acetate, methanol, 2-butanol, 1-propanol, 2-metil1-propanol, 2-propene-1-ol, 1-butanol, 2-methil-1-butanol, 3-methil-1-butanol in wines. Comissao de Viticultura da Regiao dos Vinhos Verdes, Rua da resstauracao, Porto, p. 318

Nikićević, N., Jović, S., Sivčev, B. (2000): Ispitivanja pogodnosti nekih novostvorenih sorti vinove loze za proizvodnju alkoholnih pića od grožđa. V Savetovanje industrije alkoholnih i bezalkoholnih pića i sirćeta, Zbornik radova, Vranjačka Banja, 123-131.

OIV (1994): Office International de la vigne et du vin, Recueil des methodes internationales d'analyse des boissons spiritueses, des alcools et de la fracton aromatique boissons. Paris.

Paunović, R.(2000): Uticaj sirovine i tehnološkog postupka proizvodnje na sadržaj viših alkohola $\mathrm{u}$ alkoholnim pićima. V Savetovanje industrije alkoholnih i bezalkoholnih pića i sirćeta, Zbornik radova, Vranjačka Banja,101-123.

Paunović, R., Đurišić, B.(1981): Prilog izučavanja načina proizvodnje i svojstva rakije lozovače. Vinogradarstvi i vinarstvo, 35-36, 89-99.

Paunović, R., Nikičević, N. (1986): Izbor sorte vinove loze za proizvodnju vinjaka. Jugoslovensko vinogradarstvo i vinarstvo, 2-3, 77-80.

Pekka, L. (1996): Determination of Amines and Amino Acids in Wine - A Review; American Journal of Enology and Viticulture, 47/2, 127-133.

Rules on the Quality of Strong Alcoholic Beverages (2003), Official Gazette of the FRY, 4, 1-10.

Regulations on Sampling Methods and Physical and Chemical Analyses of Spirits (1987), Official Gazette of the SFRY, 70, 1646-1654. 
Puškaš, V . (2002): Uticaj dodatka neorganskog azota i cinka u širu na količinu viših alkohola u vinu. VI Savetovanje industrije alkoholnih i bezalkoholnih pića i sirćeta, 123-126.

Petkov, M., Božinović, Z., Milanov, G., Vojnovski, V. (1998): Влијание на технолошките постапки врз квалитетните особини на лозовите ракии. Зборник на научни трудови, I Македонски симпозиум по лозарство и винарство со мегунардно учешће, Скопје, 223-227.

Stanković, S., Živković, J., Ranković V., (1998): Ефектот од таложењето на ширата врз составот и квалитетот на винскиот дестилат. Зборник на научни трудови, I Македонски симпозиум по лозарство и винарство со мегунардно учешће, Скопје, 167-171. 


\title{
UTICAJ ALKOHOLNE FERMENTACIJE NA KVALITET RAKIJE LOZOVAČE
}

\author{
Vera Vukosavljević ${ }^{1}$, Ranković Vesna ${ }^{2}$, \\ Dragoljub Žunić ${ }^{3}$, Saša Matijašević ${ }^{3}$ \\ ${ }^{1}$ Agronomski fakultet u Čačku, Cara Dušana 34 Čačak, Srbija \\ ${ }^{2}$ Centar za vinogradarstvo i vinarstvo, Kolonija EL 6, Niš, Srbija \\ ${ }^{3}$ Poljoprivredni fakultet,Zemun, Nemanjina 6, Beograd, Srbija
}

\begin{abstract}
Rezime
Lozovača ili lozova rakija predstavlja proizvod koji se dobija fermentacijom i destilacijom celog kljuka grožđa plemenite vinove loze Vitis vinifera. Kvalitet rakije lozovače zavisi od velikog broja faktora: sorte vinove loze, klime, zemljišta, vremena $\mathrm{i}$ načina destilacije, načina čuvanja destilata $\mathrm{i} \mathrm{dr}$. Za realizaciju ovog eksperimenta korišćeno je grožđe sorte vinove loze 'Neoplanta' koja se gaji na oglednom imanju PD »Centar za vinogradarstvo i vinarstvo« u Nišu. Ispitivanja su izvedena $u$ laboratorijskim uslovima Centra. Zdravo i tehnološki zrelo grožđe je izmuljano električnom muljačom koja odvaja peteljke. Fermentacija celokupnog kljuka grožđa je izvršena u plastičnim vrionim posudama u prisustvu autohtone mikroflore vinskih kvasaca.

$\mathrm{U}$ radu je prikazan uticaj $\mathrm{pH}$ vrednosti i neorganskog azota dodatog $\mathrm{u}$ fermentacionu smešu na sadržaj isparljivih komponenti i koncentraciju viših alkohola.

Ključne reči: lozova rakija, grožđe, viši alkoholi, sorta, Neoplanta
\end{abstract}

